\title{
METHOD FOR THE PRESERVATION AND STERILIZATION OF FRESH DONOR MATERIAL FOR FULL-THICKNESS KERATOPLASTY BY FRAMYCETIN*
}

\author{
BY \\ PETER RYCROFT \\ Department of Pathology, Institute of Ophthalmology, London $\dagger$
}

THE pioneer of corneal graft preservation was Magitot (1911; 1912a, b), who preserved rabbit corneae in 4 per cent. formalin and produced "dead" grafts; later he used haemolysed serum cooled to $+5^{\circ} \mathrm{C}$. He recorded a successful human lamellar corneal graft where the donor material had been so preserved for eight days.

Schimanowski $(1912 ; 1913)$ performed a successful keratoplasty from an enucleated eye preserved for ten days at low temperature. About twenty years later Filatov $(1931 ; 1935 ; 1947)$ carried on this work. Initially, he preserved donor eyes in serum or citrated donor blood at low temperature for up to six days, but later he preferred the absence of preserving fluid at $2-4^{\circ} \mathrm{C}$. which he asserted improved the viability of the graft.

Other workers later tried and mostly discarded preservation in Ringer's, Tyrode's, and Hartmann's solutions, together with physiological saline; the corneae became hazy on or after the third day (Castroviejo, 1941; Thomas, 1946; Katzin, 1947a, b).

Later, the technique of Burki (1947) seemed the most reliable (Franceschetti, 1948). Rabbit corneal discs preserved in liquid paraffin at $4^{\circ} \mathrm{C}$. retained both transparency and vitality, and when preserved in this way for two to eight days they healed cleanly in rabbit hosts to remain transparent up to one year post-operatively.

More recently, Rycroft (1953a, b; 1954) thought that a suspension of penicillin and streptomycin powder in the paraffin medium would aid sterilization of the donor material. Pre-operation culture of the donor had become a routine procedure in many centres, and eyes growing pathogens were discarded.

The view that freshness of the donor material gives the highest proportion of clear penetration grafts became universally accepted (Townley Paton, 1955). The additional thirty-six hours which must ensue in order to obtain a culture report of a post-mortem eye undoubtedly reduces its viability, and may prejudice the success of the graft. Nevertheless, a culture of the donor eye must always be taken if the surgeon considers sterility to be in doubt, and to establish organism-antibiotic sensitivity for later use if infection supervenes.

The modern methods of short-term preservation must combine efficient sterilization with minimal impairment of viability.

* Received for publication June 23, 1964.

† Present address: Pocklington Eye Research Unit, Royal College of Surgeons, Lincoln's Inn Fields, London. 


\section{Storage of Donor Eyes in Liquid Paraffin}

During the years 1960 to 1962 this method of preservation was employed at Moorfields Eye Hospital. An overall average of 55 per cent. of these eyes was discarded because of positive growth of pathogens on blood agar. The eyes were taken aseptically and placed in liquid paraffin and antibiotic suspension. On receipt at the hospital paraffin was drained off and a snippet of conjunctiva taken at the same time as the culture, replacing the eye in antibiotic-paraffin suspension afterwards.

Since 70-80 per cent. of all the donor eyes received were discarded, "dirty" cultures constitute the largest single cause, as is shown in Table I.

TABLE I

TOTAL OF EYES USED AND DISCARDED

\begin{tabular}{c|c|c|c}
\hline Year & $\begin{array}{c}\text { Total Eyes } \\
\text { Cultured }\end{array}$ & $\begin{array}{c}\text { "Dirty" Cultures } \\
\text { on Blood Agar }\end{array}$ & $\begin{array}{c}\text { Percentage of Total } \\
\text { No. of Eyes }\end{array}$ \\
\hline 1960 & 183 & 106 & 58 \\
1961 & 228 & 114 & 50 \\
1962 & 267 & $\frac{155}{375}$ & $\frac{58}{55}$ \\
\hline
\end{tabular}

This high proportion is probably due to the ineffectiveness of the antibiotic suspension in an oil medium. From a series of 20 eyes preserved in this medium at $+4{ }^{\circ} \mathrm{C}$. it was possible in 3 cases to grow the pathogens direct from the paraffin itself, confirming inefficient sterilization. Moreover, eyes stored in paraffin are technically difficult to clean thoroughly without damaging the graft, and in some cases paraffin oil has been seen in the anterior chamber after operation.

\section{Present Study}

The purpose of this study was to develop a technique of preservation and "washing" of a fresh donor eye so that it could be used quickly, and so that the surgeon could expect it to be sterile and viable. The experiments were subdivided into four parts:

(1) A controlled study of active solutions of 0.5 per cent. and 1 per cent. framycetin, against an 0.9 per cent. saline control solution to determine relative effectiveness of sterilization.

(2) The sterilizing effect of leaving 0.5 per cent. framycetin in contact with a donor eye for 15,30 , and 60 minutes.

(Both these studies were conducted as "blind" trials using numbered bottles, which did not indicate whether the solution under trial was active or control.)

(3) Biological assessment of the relative reduction of viability of corneal tissue resulting from contact with framycetin.

(4) Clinical trials to show the results of graft sterilization by this technique, its effects on viability, and complications.

\section{Choice of Antibiotics}

A survey of 91 donor eyes with "dirty" cultures showed that the commonest pathogens were: Escherichia coli, 33; Staphylococcus aureus coagulase positive, 29; Staph. albus coagulase positive, 17; Neisseria catarrhalis, 5; Diphtheroids, 3; Proteus vulgaris, 4. 
The most suitable antibiotic available at the time of the trial was framycetin sulphate (Soframycin, Roussel). The spectrum of this antibiotic included all the above bacteria, with the important addition of many strains of Pseudomonas aeruginosa, which, although a rare contaminant of donors, is the most significant (Bertoye and Courtieu, 1954; MassenatDeroche, 1954; Ainslie and Henderson, 1958).

The other advantages of this antibiotic for this work are:

(1) It is very stable in solution.

(2) It stores indefinitely.

(3) It is slightly hypertonic-equivalent to 1.004 per cent. saline-thus maintaining relative corneal dehydration (Adler, 1959). A solution of 0.5 per cent. framycetin in $1 \cdot 1$ per cent. saline is equivalent in tonicity to that of 1.2 per cent. saline alone.

(4) It is used clinically with success against all these organisms, including Ps. aeruginosa (Ainslie and Cairns, 1960; Rycroft, 1955; 1962) and is given as a routine procedure under the conjunctiva by some surgeons after keratoplasty.

(5) In the strength of 0.5 per cent. there is no visible effect upon the graft. The surgeons could not attribute any clinical failures to the use of this antibiotic, though Rycroft has warned of possible uveal irritation.

Its disadvantage is that, like many antibiotics, it is cytotoxic, and the longer it is in contact with the donor eye the more it will impair its vitality. Furthermore, it is not effective against all strains of streptococci.

\section{Pharmaceutical Aspects of Framycetin}

Mr. F. Summers, the pharmacist to the Queen Victoria Hospital, East Grinstead, undertook much of the original work on this subject before recommending it for use in the Ophthalmic Department. The author is indebted to him for the account that follows:

"When framycetin sulphate was introduced several years ago the only preparation available was an ointment for dermatological use. However, this antibiotic had several properties which led us to examine it with a view to extending its use. First, it was remarkably stable, solutions retaining stability for several months at room temperature. Secondly, its antimicrobial spectrum was interesting. Its action against the streptococcus was not remarkable, but it was particularly effective against staphylococci and many strains of Pseudomonas aeruginosa.

The average sensitivity ranges of the principal pathogenic bacteria are:

Staphylococci: 1 to $10 \mu \mathrm{g} . / \mathrm{ml}$. with a considerable proportion sensitive to less than $1 \mu \mathrm{g} . / \mathrm{ml}$.

Streptococci: Up to $100 \mu \mathrm{g} . / \mathrm{ml}$.

Ps. aeruginosa: Up to $20 \mu \mathrm{g} . / \mathrm{ml}$.

Proteus: Up to $20 \mu \mathrm{g} . / \mathrm{ml}$. with $P$. vulgaris being the most sensitive.

Esch. coli: 10 to $100 \mu \mathrm{g} . / \mathrm{ml}$.

The possibility occurred to us of using this antibiotic as a preservative for eye drops, but we have not yet followed up this promising line. However, we did examine the use of this antibiotic as a sterilizing agent for donor eyes, and we have found it satisfactory from a clinical aspect.

The following chemical and physical data may be of use to other users of the drug:

Framycetin is closely related to streptomycin and neomycin. All three are amino-sugars and have similar properties. The amino-sugar released upon acid hydrolysis gives the Elson-Morgan reaction which can be used to devise a colorimetric method of assay. We have been reluctant to use this method in stability studies as we have no information of the presence of inactive metabolic breakdown products in our solutions which would give a positive reaction. Micro-biological methods of assay are preferable, and the serial dilution technique is the one normally used as the antibiotic diffuses poorly through agar. However, satisfactory diffusion occurs if the agar is adjusted to a $\mathrm{pH}$ of 8.0 to 8.5 and incorporates a phosphate buffer. At present we know of no suitable inactivator for the antibiotic, and the original French workers suggest that nutrient media should be diluted to contain less than $1 \mu \mathrm{g}$. of framycetin per $15 \mathrm{ml}$. of broth to ensure growth of any viable organisms. 
Framycetin sulphate is very soluble in water and insoluble in oils. In aqueous solution it is most stable at a pH of 6.3. Unadjusted solutions have a $\mathrm{pH}$ of around $6 \cdot 5$.

When donor eyes are stored for several days in isotonic solutions the globe collapses, presumably owing to diffusion of fluid from eye to solution. We therefore made our solutions of the antibiotic in plain sterile water, but later decided to adjust the $\mathrm{pH}$ to just over 7.0. The addition of tribasic sodium phosphate in a concentration of 0.1 per cent. is enough to achieve the desired effect."

"Blind" Trials.-Old "dirty" culture eyes preserved in liquid paraffin were used in order to obtain a high concentration of pathogens, and to render the test a strenuous one. Solutions were made up as follows:

(1) Sodium citrate 0.2 per cent.; citric acid 0.02 per cent.; sodium chloride 0.6 per cent.; phenyl mercuric nitrate 0.001 per cent.; water to 100 per cent. This solution was subjected to autoclave sterilization and 1 per cent. framycetin was added under aseptic conditions.

(2) As above, adding 0.5 per cent. framycetin.

(3) Saline controls 0.9 per cent.

\section{Technique}

Donor eyes were transferred aseptically from liquid paraffin to be washed in an unknown bottle for 30 minutes; most of the liquid paraffin was allowed to drain off before transfer. After 30 minutes $0.5 \mathrm{ml}$. was withdrawn from the trial solution into a sterile pipette; 3 drops were added to a sterile tube of $20 \mathrm{ml}$. nutrient broth medium for aerobic culture and to Robertson's meat medium for anaerobic culture. The tubes were incubated for 36 hours at $+37^{\circ} \mathrm{C}$. and the results were recorded. Where the culture was positive the organism grown was recorded for comparison with the original pathogen at the Institute of Ophthalmology, London.

\section{(1) 1 per cent. Framycetin Trial}

\section{Results}

Forty-one eyes were used; of these, 19 were treated with 1 per cent. framycetin for 30 minutes and 22 with the saline control, also for 30 minutes. The experiment was conducted as a "blind" study so that the author was unaware whether the solutions under trial were active or control.

The active-framycetin-solutions sterilized 18 out of 19 eyes, in aerobic and anaerobic culture. The positive culture eye grew an anaerobic coliform bacillus in the trial where an aerobic Staphylococcus aureus had been recorded as the original pathogen.

Of the control eyes, 11 out of 22 were sterile in aerobic and anaerobic culture.

It was concluded that a thorough but gentle washing reduces the incidence of contaminants in the culture of donor eyes, and that while simple washing of the eye in saline is helpful, the use of framycetin is much more effective.

\section{(2) 0.5 per cent. Framycetin Trial}

In this trial 18 eyes were used; 9 were washed with active framycetin solution, and 9 with the saline control. Framycetin produced sterile cultures in 7 out of 9 eyes, the two positive ones being in aerobic culture only. The saline solution sterilized only 3 out of 9 eyes in aerobic and anaerobic culture.

A further trial of 30 eyes followed. They were first washed free of liquid paraffin 
and then washed in 0.5 per cent. framycetin over a variable time of 60 minutes, 30 minutes, and 15 minutes; the results are recorded in Tables II, III, and IV. These were aerobic cultures of 36 hours on blood agar plates.

These results show that not one colony was grown after washing with framycetin; this is partly attributable to the removal of most of the paraffin by 0.9 per cent. sterile saline before exposure to framycetin.

Although not perfect, it was felt that the sterility achieved by this technique was more certain that that achieved by using liquid paraffin and attempts to evaluate the biological effects were made.

\section{Biological Effects}

Dr. A. U. Smith of the Medical Research Council, Mill Hill, investigated the effects of 0.5 per cent. framycetin on rabbit corneal epithelium grown in tissue culture to assess viability. The constant presence of framycetin in the culture medium inhibited the growth of established cultures of corneal epithelium and killed them within four days.

TABLE II

FRAMYCETIN 0.5 PER CENT. WASHING FOR ONE HOUR

\begin{tabular}{|c|c|c|c|c|}
\hline Eye & $\begin{array}{l}\text { Hours Post } \\
\text { Mortem }\end{array}$ & $\begin{array}{l}\text { Culture Report from } \\
\text { Institute of Ophthalmology }\end{array}$ & $\begin{array}{l}\text { Culture of } \\
\text { Liquid Paraffin }\end{array}$ & $\begin{array}{l}\text { Culture } \\
\text { of Eye }\end{array}$ \\
\hline 1 & 3 hours & Staph. albus coagulase positive & No growth & No growth \\
\hline 2 & 3 hours & Staph. albus coagulase positive & No growth & No growth \\
\hline 3 & Same day & Staph. aureus coagulase positive & No growth & No growth \\
\hline 4 & Same day & Coliform bacilli & No growth & No growth \\
\hline 5 & 5 hours & $\begin{array}{l}\text { Staph. aureus coagulase positive } \\
\text { Diphtheroids }\end{array}$ & Growth positive & No growth \\
\hline
\end{tabular}

TABLE III

FRAMYCETIN 0.5 PER CENT. WASHING FOR HALF-AN-HOUR

\begin{tabular}{|c|c|c|c|c|}
\hline Eye & $\begin{array}{l}\text { Hours Post } \\
\text { Mortem }\end{array}$ & $\begin{array}{l}\text { Culture Report from } \\
\text { Institute of Ophthalmology }\end{array}$ & $\begin{array}{c}\text { Culture of } \\
\text { Liquid Paraffin }\end{array}$ & $\begin{array}{l}\text { Culture } \\
\text { of Eye }\end{array}$ \\
\hline 1 & 3 hours & Staph. albus coagulase positive & No growth & No growth \\
\hline 2 & Unknown & Staph. aureus coagulase positive & No growth & No growth \\
\hline 3 & Unknown & Staph. aureus coagulase positive & Growth positive & No growth \\
\hline 4 & Unknown & Staph. aureus coagulase positive & No growth & No growth \\
\hline 5 & Unknown & Staph. aureus coagulase positive & No growth & No growth \\
\hline 6 & Unknown & Coliform bacilli & No growth & No growth \\
\hline 7 & Unknown & Staph. albus coagulase positive & No growth & No growth \\
\hline 8 & 6 hours & Coliform bacilli & No growth & No growth \\
\hline 9 & 6 hours & Coliform bacilli & No growth & No growth \\
\hline 10 & 6 hours & Staph. aureus coagulase positive & Growth positive & No growth \\
\hline 11 & 6 hours & Staph. aureus coagulase positive & No growth & No growth \\
\hline 12 & Unknown & Staph. aureus coagulase positive & No growth & No growth \\
\hline 13 & Unknown & Staph. aureus coàgulase positive & No growth & No growth \\
\hline 14 & Unknown & Coliforms coagulase positive & No growth & No growth \\
\hline 15 & Unknown & Coliforms coagulase positive & No growth & No growth \\
\hline
\end{tabular}


TABLE IV

FRAMYCETIN 0.5 PER CENT. WASHING FOR 15 MINUTES

\begin{tabular}{|c|c|c|c|c|}
\hline Eye & $\begin{array}{l}\text { Hours Post } \\
\text { Mortem }\end{array}$ & $\begin{array}{c}\text { Culture Report from } \\
\text { Institute of Ophthalmology }\end{array}$ & $\begin{array}{c}\text { Culture of } \\
\text { Liquid Paraffin }\end{array}$ & $\begin{array}{l}\text { Culture } \\
\text { of Eye }\end{array}$ \\
\hline 1 & Unknown & $\begin{array}{l}\text { Coliform } \\
\quad \text { Staph. aureus coagulase positive }\end{array}$ & $\begin{array}{l}\text { No growth } \\
\text { No growth }\end{array}$ & $\begin{array}{l}\text { No growth } \\
\text { No growth }\end{array}$ \\
\hline 2 & Unknown & Staph. albus coagulase positive & No growth & No growth \\
\hline 3 & Unknown & Coliform & No growth & No growth \\
\hline 4 & Unknown & Coliform & No growth & No growth \\
\hline 5 & $8 \frac{1}{2}$ & Coliform & No growth & No growth \\
\hline 6 & $8 \frac{1}{2}$ & Staph. aureus coagulase positive & No growth & No growth \\
\hline 7 & Unknown & $\begin{array}{l}\text { Staph. aureus coagulase positive } \\
\text { Coliform }\end{array}$ & $\begin{array}{l}\text { No growth } \\
\text { No growth }\end{array}$ & $\begin{array}{l}\text { No growth } \\
\text { No growth }\end{array}$ \\
\hline 8 & Unknown & Proteus & No growth & No growth \\
\hline 9 & $3 \frac{1}{2}$ & Proteus & No growth & No growth \\
\hline 10 & & Proteus & No growth & No growth \\
\hline
\end{tabular}

No culture report of Pseudomonas aeruginosa came to hand during our experiments.

A further experiment was performed using 32 portions of epithelium and stroma together. One half of the portions (16) was soaked in 0.5 per cent. framycetin for one hour in the tissue culture medium. They were then washed thoroughly and subjected to tissue culture. The other half (16) was treated with penicillin and streptomycin as a control and put in tissue culture.

After five days, only one of the framycetin-treated portions showed a vigorous growth and the other 15 portions had scanty or no growth. All the controls after penicillin and streptomycin treatment were growing vigorously (Smith, 1963).

It has not so far been possible to assess the effect on corneal endothelium after half-an-hour's washing in the framycetin, and to this extent the surgical results obtained have outstripped the laboratory. Now that endothelial tissue cultures are more practicable, experiments are proceeding in this field.

\section{Clinical Results}

Since $1959,0 \cdot 5$ per cent. framycetin has been used as a routine washing agent at the Corneo-Plastic Eye Unit, East Grinstead (Rycroft, 1962). The eyes are removed as soon as possible after death with appropriate aseptic precautions. They are carefully placed, cornea uppermost, in a wide-mouth dry sterile jar and stored in a refrigerator at $+4^{\circ} \mathrm{C}$. There is no immediate application of any antibiotic. The gift of a refrigerated van to the hospital has been of great assistance for this purpose: eyes are rapidly collected, examined, and brought to storage. These eyes are used within three days for optical penetration grafts, but frequently they have been used on the day of death owing to the speedy organization of collection.

Immediately before operation the eye is soaked in 0.5 per cent. framycetin for 15 to 20 minutes, at operation theatre temperature, and is then washed in 0.9 per cent. sterile saline in order to remove the antibiotic before the graft is cut.

After operation, the donor eye is sent immediately for routine culture to determine the presence of organisms and their drug sensitivity.

By the time the culture and sensitivity report is received, the graft is partially epithelialized in the host, and it has been in constant contact with local antibiotic ointment. 
The results of 166 penetration corneal grafts at East Grinstead which were washed in 0.5 per cent. framycetin for 20 minutes, showed only 4 "dirty" cultures. Three of these were from Monilia, and one from Staph. aureus, coagulase positive. Not one of these patients developed post-operative infection of the graft despite the adverse culture reports.

The surgeons do not attribute any of the clinical failures of the grafts to the use of framycetin, and the normal proportion of failures has not been increased as a result of this method of sterilization. The slit-lamp appearances and post-operative union showed that the grafts were quite unaffected by the washing agent.

Nevertheless, there is a definite clinical impression that there is more anterior uveitis in some of these cases than occurred in previous series using other methods of sterilization. The uveitis cannot be attributed directly to framycetin, as it did not occur in all the cases.

\section{Discussion}

This trial raised several points worthy of discussion and further evaluation. In the first instance, it is not claimed that this technique is perfect, but it is definitely more efficient that than of liquid paraffin.

Massenat-Deroche (1954) found 80 per cent. of 20 strains of Pseudomonas aeruginosa to be sensitive to less than $20 \mu \mathrm{g} . / \mathrm{ml}$. framycetin. In this trial a strength of $37.5 \mu \mathrm{g} . / \mathrm{ml}$. was used, and as there is no anti-framycetin factor, it was probably still effective during incubation.

In this context, Summers (1964) states that a strength of $0 \cdot 25$ per cent. framycetin should still be adequate to produce sterilization of donor eyes. A further trial along these lines is proving successful at East Grinstead. Framycetin 0.25 per cent. represents $2,500 \mu \mathrm{g} . / \mathrm{ml}$., which is well in excess of the minimum sensitivity. Moreover, it is not necessary to use phenylmercuric nitrate as a preservative, in the light of the stability of framycetin.

Since no infected grafts have resulted from using the washing technique it may be concluded that the most important problem is that of impairment of graft viability, as has been shown in rabbit cornea by tissue culture standards. The post-mortem viability of eye tissues is unknown, and more especially that of the corneal endothelium, upon which depends the success or failure of the penetration graft.

Clinical results suggest that 15 to 20 minutes immersion in 0.25 per cent. or 0.5 per cent. framycetin does not markedly damage endothelial viability, but confirmation of this has yet to come from tissue culture experiments.

Further studies on these problems are in progress at the Pocklington Eye Transplantation Unit at the Royal College of Surgeons.

\section{Summary}

A technique of short-term preservation of donor eyes for penetration keratoplasty with sterilization by 0.5 per cent. framycetin is described.

Controlled bacteriological trials, biological evidence, and 166 human keratoplasties performed without sepsis or loss of viability, are reported. 19 
The author wishes to thank the following for their co-operation and encouragement: Prof. N. H. Ashton, Prof. Barrie Jones, Sir Benjamin Rycroft, Mr. F. Summers, Mr. F. W. Law, Dr. Audrey Smith, the theatre sisters and the pharmacy of Moorfields Eye Hospital, Sister K. King, Mrs. M. Young of Roussel Ltd., who kindly made available the Soframycin, and Dr. H. Lee of Genatosan Ltd.

Mr. Summers (East Grinstead) wishes to thank the Medical Department of Roussel Laboratories for information supplied over the past seven years.

\section{REFERENCES}

Adler, F. H. (1959). "Physiology of the Eye", Section on Cornea, chap. 3, p. 61. Mosby, St. Louis. Ainslie, D., and Henderson, W. G. (1958). Brit. J. Ophthal., 42, 513. - and CAIRns, J. E. (1960). Ibid., 44, 25.

Bertoye, A., and Courtieu, A. L. (1954). C. R. Soc. Biol. (Paris), 148, 1412.

BURKI, E. (1947). Ophthalmologica (Basel), 114, 288.

Castroviejo, R. (1941). Amer. J. Ophthal., 24, 139.

Filatov, V. P. (1931). Lancet, 1, 1395. (1935). Arch. Ophthal. (Chicago), 13, 321. (1947). Excerpta med. (Amst.), Sect. XII, 5.

Franceschetti, A. (1948). Montpellier med., 3 ser., 33-34, 115.

Katzin, H. M. (1947a). Arch. Ophthal. (Chicago), 37, 379. (1947b). Amer. J. Ophthal., 30, 1128.

Magitot, A. (1911). Ann. Oculist. (Paris), 146, 1. - (1912a). Arch. Ophtal. (Paris), 32, 584. (1912b). J. Amer. med. Ass., 59, 18.

Massenat-Deroche, B. (1954). "La framycetine-un nouvel antibiotique". Thesis for M.D. (Paris).

Paton, R. Townley (1955). "Keratoplasty", chap. 6, p. 113. McGraw-Hill, New York.

RYCROFT, B. W. (1953a). Brit. J. Ophthal., 37, 349. (1953b). Ibid., 37, 351. (1954). Ibid., 38, 1. (1955). "Corneal Grafts", ed., chap. 12, p. 195. Butterworth, London. (1962). Lancet, 1, 147.

Schimanowski, A. (1912). Vestn. Oftal., 29, 711, 813. (1913). Klin. Mbl. Augenheilk., 51, 870.

Smith, A. U. (1963). Personal communication. Summers, F. (1964). Personal communication.

Thомas, C. I. (1946). Arch. Ophthal. (Chicago), 36, 321. 